Supporting Information

\title{
Molecular Engineered Squaraine Nanoprobe for NIR-II/Photoacoustic Imaging and Photothermal Therapy of Metastatic Breast Cancer
}

Defan Yao, ${ }^{\dagger}, "$ Yanshu Wang, ${ }^{\dagger}$ Rongfeng Zou, ${ }^{\S}$ Kexin Bian, ${ }^{*}$ Pei Liu, ${ }^{*}$ Shuzhan Shen, ${ }^{*}$ Weitao Yang, ${ }^{+}$Bingbo Zhang, ${ }^{*}, \dot{+}$ and Dengbin Wang ${ }^{*}, \dot{\dagger}$

$\dagger$ Department of Radiology, Xinhua Hospital, Shanghai Jiao Tong University School of Medicine, 200092, Shanghai, China.

$\$$ The Institute for Translational Nanomedicine, Shanghai East Hospital; The Institute for Biomedical Engineering \& Nano Science, Tongji University School of Medicine, 200092, Shanghai, China

"State Key Laboratory of Molecular Engineering of Polymers, Fudan University, 200433, Shanghai, China.

$\S$ Division of Theoretical Chemistry and Biology, School of Biotechnology, KTH Royal Institute of Technology, AlbaNova University Center, 106 91, Stockholm, Sweden

\section{Corresponding Author}

*E-mail: wangdengbin@xinhuamed.com.cn

*E-mail: bingbozhang@tongji.edu.cn 


\section{Materials and Reagents.}

Anhydrous toluene, tetrahydrafuran (THF) and n-butanol were purchased from Sigma Aldrich. The water was purified by Millipore filtration system. Both DSPE-PEG2000 and DSPE-PEG2000-Mal were supplied by Aladdin Chemistry Co., Ltd. (China). 4'-6-diamidino-2-phenylindole (DAPI) and CCK-8 were purchased from Beyotime (China). The targeting peptide CREKA (Cys-Arg-Glu-Lys-Ala) was purchased from ChinaPeptides Co., Ltd (China). Other reagents and chemicals in AR grade were purchased from Adamas-beta ${ }^{\circledR}$ (Shanghai, China) Ltd.

\section{Characterization.}

The ${ }^{1} \mathrm{H}-\mathrm{NMR}$ and ${ }^{13} \mathrm{C}-\mathrm{NMR}$ were obtained at room temperature with a Bruker AV 400 spectrometer. High-resolution mass spectra were obtained on a Waters Micromass ${ }^{\circledR}$ Q-TOF (electronic spray ionization, ESI) spectrometer. The molecular mass of peptide were acquired on an AB Sciex (MALDI-TOF) mass spectrometer. The UV/vis and photoluminescence (PL) spectra were acquired with a Varian Cary 100 Conc UV-visible spectrometer and a fluorescence spectrometer (F900, Edinburgh Instruments Ltd.), respectively. The hydrodynamic diameters and high-resolution images of nanoparticles were acquired on Nano-ZS (Zatasizer, Malvern) instrument and a JEM-2100 electron microscope (JEOL, Japan), respectively. Photoacoustic characterization was conducted with a PA microscopy system(Vevo LAZR, VisualSonics). Density functional theory (DFT) calculation was conducted by the Gaussian 09 program.

\section{Synthesis of squaraine dyes}

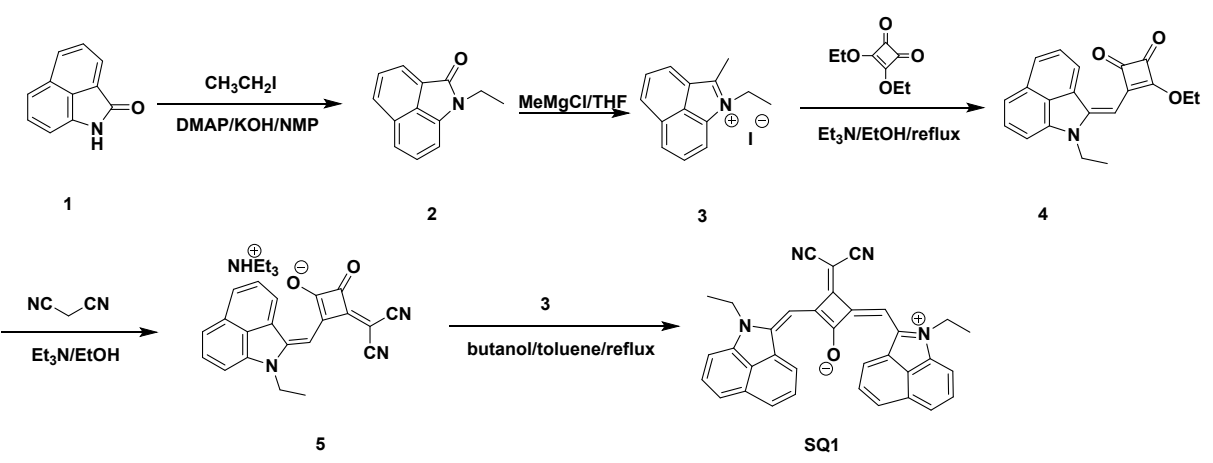

Figure S1 Synthetic route of SQ1.

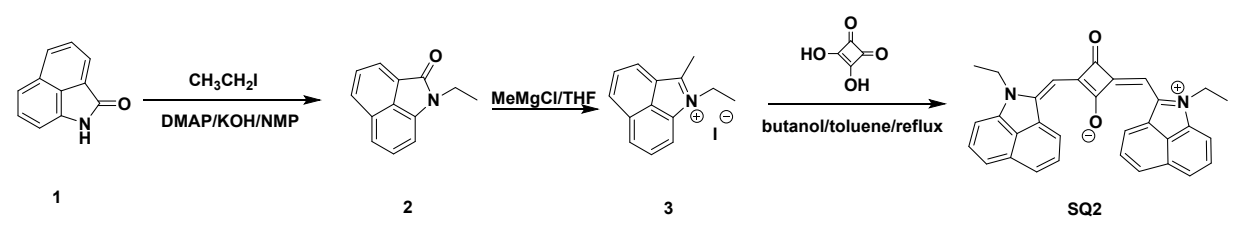

Figure S2 Synthetic route of SQ2. 
Synthesis of compound 2. A suspension of 1 (2.6 g, $15.1 \mathrm{mmol})$, iodoethane (3.5 $\mathrm{mL}, 22.7 \mathrm{mmol})$, 4-dimethyl-aminopyridine (DMAP) $\quad\left(\begin{array}{llllllll}0.25 & \mathrm{~g} & 2.1 \mathrm{mmol}) & \text { and } \mathrm{KOH} & (1.5 \mathrm{~g}, & 27.2 \mathrm{mmol}\end{array}\right)$ in 1-methyl-2-pyrrolidinone (NMP) $(100 \mathrm{~mL})$ was stirred overnight at $70{ }^{\circ} \mathrm{C}$. The heating was stopped and the solvent was cooled to room temperature, diluted with ethylacetate $(200 \mathrm{ml})$ and transferred to a separating funnel. The solution was washed with water and the aqueous phase was extracted with ethylacetate. The combined organic phases were washed successively with a solution of $15 \% \mathrm{NaCl}, 15 \% \mathrm{NaCl}$ containing $4 \% \mathrm{HCl}, 15 \% \mathrm{NaCl}$ containing $1 \% \mathrm{NaHCO}_{3}$ and $25 \% \mathrm{NaCl}$. Afterwards, the solvent was removed under reduced pressure and the solid residue was purified by column chromatography on silica gel to give 2 (2.5 g, $84.2 \%$ ) as a yellow solid. ${ }^{1} \mathrm{H}$ NMR (400 MHz, DMSO- $\left.d_{6}\right): \delta=1.26(\mathrm{t}, \mathrm{J}=7.2 \mathrm{~Hz}, 1 \mathrm{H}), 3.92(\mathrm{q}, \mathrm{J}=7.2 \mathrm{~Hz}$, 1H), $7.20(\mathrm{~d}, \mathrm{~J}=7.0 \mathrm{~Hz}, 1 \mathrm{H}), 7.55(\mathrm{dd}, \mathrm{J}=8.4,7.1 \mathrm{~Hz}, 1 \mathrm{H}), 7.63(\mathrm{~d}, \mathrm{~J}=8.4 \mathrm{~Hz}, 1 \mathrm{H}), 7.80(\mathrm{dd}, \mathrm{J}=8.0,7.1$ $\mathrm{Hz}, 1 \mathrm{H}), 8.04$ (d, J = 7.0 Hz, 1H), 8.17 (d, J = 8.1 Hz, 1H). ${ }^{13} \mathrm{C}$ NMR (100 MHz, DMSO-d $)$ : 13.79, 34.34, 105.40, 119.91, 123.84, 124.22, 125.98, 128.63, 128.82, 130.88, 138.45, 166.54. HRMS-ESI (m/z): calcd for $\mathrm{C}_{13} \mathrm{H}_{11} \mathrm{NO}, 197.0841$, found [M-I] $]^{+}, 198.0924$.

Synthesis of compound 3. Compound 2 (1.5 g, $7.6 \mathrm{mmol})$ was dissolved in dry THF (15 ml) and a solution of $\mathrm{MeMgCl}(5.1 \mathrm{ml}, 3.0 \mathrm{M}$ in THF, $2.0 \mathrm{eq})$ was added dropwise over $10 \mathrm{~min}$. The reaction mixture was heated to $60{ }^{\circ} \mathrm{C}$ for $1 \mathrm{~h}$. After cooling to room temperature, the reaction mixture was poured slowly into an ice/water mixture $(50 \mathrm{ml})$ containing $2.5 \mathrm{ml}$ of $32 \% \mathrm{HCl}$. The aqueous mixture was added of $\mathrm{KI}(2.5 \mathrm{~g}$, $15.2 \mathrm{mmol}, 2.00 \mathrm{eq})$. The red precipitate was filtered, washed with water and ethylacetate and dried under vacuum to give compound 3 as a red solid $(1.9 \mathrm{~g}, 77.2 \%) .{ }^{1} \mathrm{H}$ NMR $\left(400 \mathrm{MHz}, \mathrm{DMSO}-d_{6}\right): \delta=1.55(\mathrm{t}, \mathrm{J}=$ $7.3 \mathrm{~Hz}, 3 \mathrm{H}), 3.25$ (s, 3H), 4.72 (q, J = 7.1 Hz, 2H), 8.02 (t, J = 7.8 Hz, 1H), 8.18 (t, J = 7.6 Hz, 1H), 8.46 (d, $\mathrm{J}=8.1 \mathrm{~Hz}, 1 \mathrm{H}), 8.55(\mathrm{~d}, \mathrm{~J}=7.4 \mathrm{~Hz}, 1 \mathrm{H}), 8.81$ (d, J = 7.9 Hz, 1H), 8.99 (d, J = $7.0 \mathrm{~Hz}, 1 \mathrm{H})$. HRMS-ESI $(\mathrm{m} / \mathrm{z})$ : calcd for $\mathrm{C}_{14} \mathrm{H}_{14} \mathrm{IN}, 323.1775$, found $[\mathrm{M}-\mathrm{I}]^{+}, 196.1126$.

Synthesis of compound 4. A portion of compound $3(0.5 \mathrm{~g}, 1.6 \mathrm{mmol})$ was dissolved in ethanol $(3 \mathrm{~mL})$ and heated to reflux. Diethyl squarate $(0.3 \mathrm{~mL}, 1.9 \mathrm{mmol})$ and triethylamine $(0.6 \mathrm{~mL})$ dissolved in ethanol $(3$ $\mathrm{mL}$ ) were added. The heating was stopped after $90 \mathrm{~min}$ and the solvent was cooled. Afterwards, the solvent was removed under reduced pressure and the solid residue was purified by column chromatography on silica gel to give $4(0.5 \mathrm{~g}, 98.9 \%)$ as a red solid. ${ }^{1} \mathrm{H}$ NMR (400 MHz, DMSO- $\left.d_{6}\right): \delta=1.28(\mathrm{dt}, \mathrm{J}=12.7,6.3$ $\mathrm{Hz}, 5 \mathrm{H}), 1.37$ (t, J = 7.1 Hz, 3H), 1.46 (t, J = 7.1 Hz, 2H), 3.93 (q, J = 7.2 Hz, 2H), 4.15 (q, J = 7.1 Hz, 1H), $4.65(\mathrm{q}, \mathrm{J}=7.1 \mathrm{~Hz}, 2 \mathrm{H}), 4.90(\mathrm{q}, \mathrm{J}=7.1 \mathrm{~Hz}, 2 \mathrm{H}), 5.88(\mathrm{~s}, 1 \mathrm{H}), 7.59-7.51(\mathrm{~m}, 2 \mathrm{H}), 7.64(\mathrm{~d}, \mathrm{~J}=8.4 \mathrm{~Hz}, 1 \mathrm{H})$, 7.84-7.73 (m, 2H), $7.94(\mathrm{~d}, \mathrm{~J}=7.3 \mathrm{~Hz}, 1 \mathrm{H}), 8.03(\mathrm{dd}, \mathrm{J}=11.4,7.5 \mathrm{~Hz}, 2 \mathrm{H}), 8.18(\mathrm{~d}, \mathrm{~J}=8.1 \mathrm{~Hz}, 1 \mathrm{H}) .{ }^{13} \mathrm{C}$ NMR (100 MHz, DMSO- $\left.d_{6}\right)$ : 12.68, 13.80, 15.23, 15.57, 34.36, 38.84, 39.05, 39.26, 39.46, 39.67, 39.88, 40.09, $70.12,84.19,104.52$, 105.46, 118.69, 119.95, 123.88, 128.87, 130.93, 138.47, 141.32, 166.56, 172.90, 183.56, 189.03. HRMS-ESI (m/z): calcd for $\mathrm{C}_{20} \mathrm{H}_{17} \mathrm{NO}_{3}, 319.3600$, found $[\mathrm{M}+\mathrm{Na}]^{+}, 342.1103$. 
Synthesis of compound 5. Triethylamine $(0.4 \mathrm{~mL})$ in ethanol $(3 \mathrm{~mL})$ was added dropwise to a solution of compound $4(0.3 \mathrm{~g}, 1.0 \mathrm{mmol})$ and malononitrile $(0.1 \mathrm{~g}, 1.5 \mathrm{mmol})$ in ethanol $(5 \mathrm{~mL})$ under stirring. The reaction mixture was stirred for $30 \mathrm{~min}$ under reflux. Afterwards, the solvent was removed under reduced pressure and the solid residue was purified by column chromatography on silica gel to give 5 ( $0.4 \mathrm{~g}, 90.9 \%)$ as a purple solid. ${ }^{1} \mathrm{H}$ NMR (400 MHz, $\left.\mathrm{CDCl}_{3}\right): \delta=1.25(\mathrm{~s}, 1 \mathrm{H}), 1.37(\mathrm{~m}, 12 \mathrm{H}), 3.24(\mathrm{~s}, 6 \mathrm{H}), 4.00(\mathrm{~d}, \mathrm{~J}=$ $6.3 \mathrm{~Hz}, 2 \mathrm{H}), 6.31$ (s, 1H), $6.74(\mathrm{~s}, 1 \mathrm{H}), 7.33(\mathrm{~s}, 1 \mathrm{H}), 7.40$ (t, J = $7.6 \mathrm{~Hz}, 1 \mathrm{H}), 7.59$ (s, 1H), 7.77 (s, 1H), 9.58 (s, 1H). ${ }^{13} \mathrm{C}$ NMR (100 MHz, DMSO-d 6 ): 12.68, 13.80, 15.23, 15.57, 34.36, 38.84, 39.05, 39.26, 39.46, 39.67, $39.88,40.09,70.12,84.19,104.52,105.46,118.69,119.95,123.88,128.87,130.93,138.47,148.51,166.56$, 172.90, 183.56, 189.03, 189.25. HRMS-ESI (m/z): calcd for $\mathrm{C}_{27} \mathrm{H}_{28} \mathrm{~N}_{4} \mathrm{O}_{2}, 440.5470$, found [M-NHEt 3 ]', 388.0941 .

Synthesis of SQ1. A portion of compound $5(0.3 \mathrm{~g}, 0.7 \mathrm{mmol})$ and compound $\mathbf{3}(0.2 \mathrm{~g}, 0.8 \mathrm{mmol})$ were heated under reflux in an $n$-butanol/toluene mixture $(10 \mathrm{~mL}, 1: 1 \mathrm{v} / \mathrm{v})$ overnight. The solvent was removed under reduced pressure and the residue was purified by column chromatography on silica gel to afford the squaraine dye SQ1 (0.4 g, 81.2\%). ${ }^{1} \mathrm{H}$ NMR (400 MHz, DMSO-d $\left.\mathrm{d}_{6}\right): \delta=1.38$ (t, J = 7.9 Hz, 3H), 3.78 (m, 4H), $6.42(\mathrm{~s}, 2 \mathrm{H}), 7.52(\mathrm{t}, \mathrm{J}=7.7 \mathrm{~Hz}, 2 \mathrm{H}), 7.56(\mathrm{t}, \mathrm{J}=7.7 \mathrm{~Hz}, 2 \mathrm{H}), 7.61(\mathrm{~d}, \mathrm{~J}=7.9 \mathrm{~Hz}, 2 \mathrm{H}), 8.07$ (m, 4H), $8.61(\mathrm{~d}, \mathrm{~J}=7.9 \mathrm{~Hz}, 2 \mathrm{H}) .{ }^{13} \mathrm{C}$ NMR (100 MHz, DMSO-d 6 ): 12.98, 24.25, 25.65, 25.76, 25.47, 26.28, 33.15, $43.79,50.48,87.65,87.77,106.51,107.16,119.12,119.80,124.57,128.07,131.45,136.08,142.56,165.70$, 177.15, 184.57, 188.92. HRMS-ESI (m/z): calcd for $\mathrm{C}_{35} \mathrm{H}_{24} \mathrm{~N}_{4} \mathrm{O}_{2}, 516.1950$, found $[\mathrm{M}+\mathrm{H}]^{+}$, 517.2036.

Synthesis of SQ2. A portion of compound $3(0.5 \mathrm{~g}, 1.6 \mathrm{mmol})$ and squaric acid $(0.1 \mathrm{~g}, 0.8 \mathrm{mmol})$ were heated under reflux in an $n$-butanol/toluene mixture $(10 \mathrm{~mL}, 1: 1 \mathrm{v} / \mathrm{v})$ for $2 \mathrm{~h}$. The solvent was removed under reduced pressure and the residue was purified by column chromatography on silica gel to afford the squaraine dye SQ2 (0.5 g, 83.3\%). ${ }^{1} \mathrm{H}$ NMR (400 MHz, DMSO-d $\left.\mathrm{d}_{6}\right): \delta=1.33$ (t, J = 8.0 Hz, 6H), 3.24 (m, 4H), 6.36 (s, 2H), 7.01 (d, J = 7.1 Hz, 2H), $7.44(\mathrm{t}, \mathrm{J}=7.7 \mathrm{~Hz}, 2 \mathrm{H}), 7.54$ (d, J = 8.2 Hz, 2H), 7.83 (t, J = 7.7 $\mathrm{Hz}, 2 \mathrm{H}), 8.01$ (d, J = 8.0 Hz, 2H), 8.52 (s, 2H). ${ }^{13} \mathrm{C}$ NMR (100 MHz, DMSO-d 6 ): 13.59, 14.60, 15.67, 16.17, $33.26,39.44,40.25,40.76,41.46,41.67,39.88,42.09$, 69.52, 83.14, 105.36, 107.96, 121.63, 125.49, 128.46, 129.60, 130.43, 138.27, 142.52, 164.26, 176.30, 183.56, 185.01. HRMS-ESI (m/z): calcd for $\mathrm{C}_{32} \mathrm{H}_{24} \mathrm{~N}_{2} \mathrm{O}_{2}, 468.1838$, found $[\mathrm{M}+\mathrm{H}]^{+}, 469.1915$.

\section{Dynamic light scattering (DLS)}

The hydrodynamic diameters of the SQ1 nanoprobe and SQ2 nanoprobe were measured using a dynamic light scattering spectrometer (DLS) on Nano-ZS (Zatasizer, Malvern) instrument. Samples of $10.0 \mu \mathrm{g} / \mathrm{mL}$ SQ1 nanoprobe or SQ2 nanoprobe in PBS buffer in a total sample 
volume of $1.0 \mathrm{~mL}$.

a)

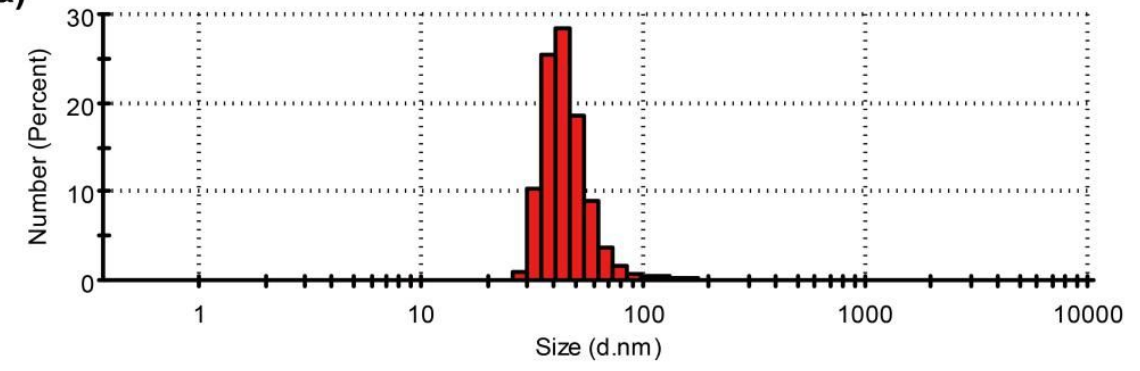

b)

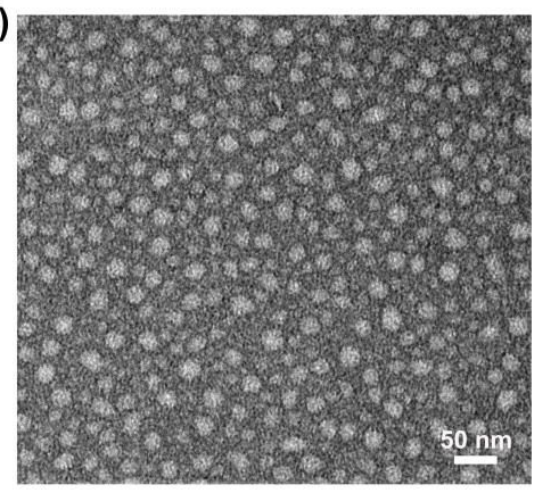

c)

Zeta Potential Distribution

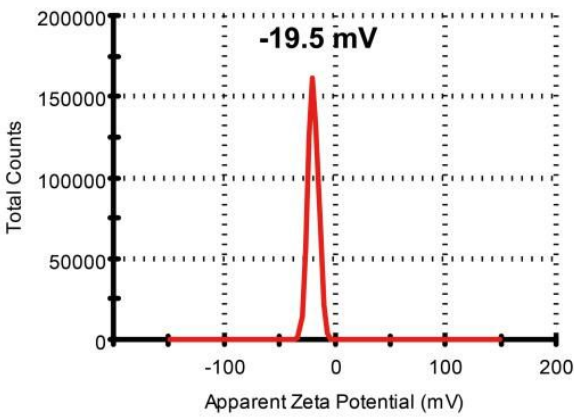

Figure S3 a) DLS profile showing hydrodynamic diameters [DH $(\mathrm{nm})]$ for SQ2 nanoprobe $(10 \mu \mathrm{g} / \mathrm{mL})$ in PBS (pH 7.4, $\left.25^{\circ} \mathrm{C}\right)$. b) TEM images of SQ2 nanoprobe $(10 \mu \mathrm{g} / \mathrm{mL})$ was stained with sodium phosphotungstate (2.0 wt $\%$ aqueous solution). c) Zeta potentials of SQ2 nanoprobe $(10 \mu \mathrm{g} / \mathrm{mL})$ in PBS (pH $\left.7.4,25^{\circ} \mathrm{C}\right)$.

\section{Transmission electron microscopy (TEM)}

High-resolution images of SQ1 nanoprobe and SQ2 nanoprobe were acquired using TEM. Samples were prepared by placing a few droplets of SQ1 nanoprobe or SQ2 nanoprobe onto a carbon-coated grid with holes and stained with sodium phosphotungstate $(2.0 \mathrm{wt} \%$ aqueous solution) and dried at room temperature. TEM characterization was performed using a JEM-2100 electron microscope (JEOL, Japan).

\section{Zeta Potential measurement}

The zeta potential was measured with Nano-ZS (Zatasizer, Malvern) instrument. Samples were dissolved in PBS buffer. All data were corrected by subtracting the value tested for a blank scan of the buffer system. 

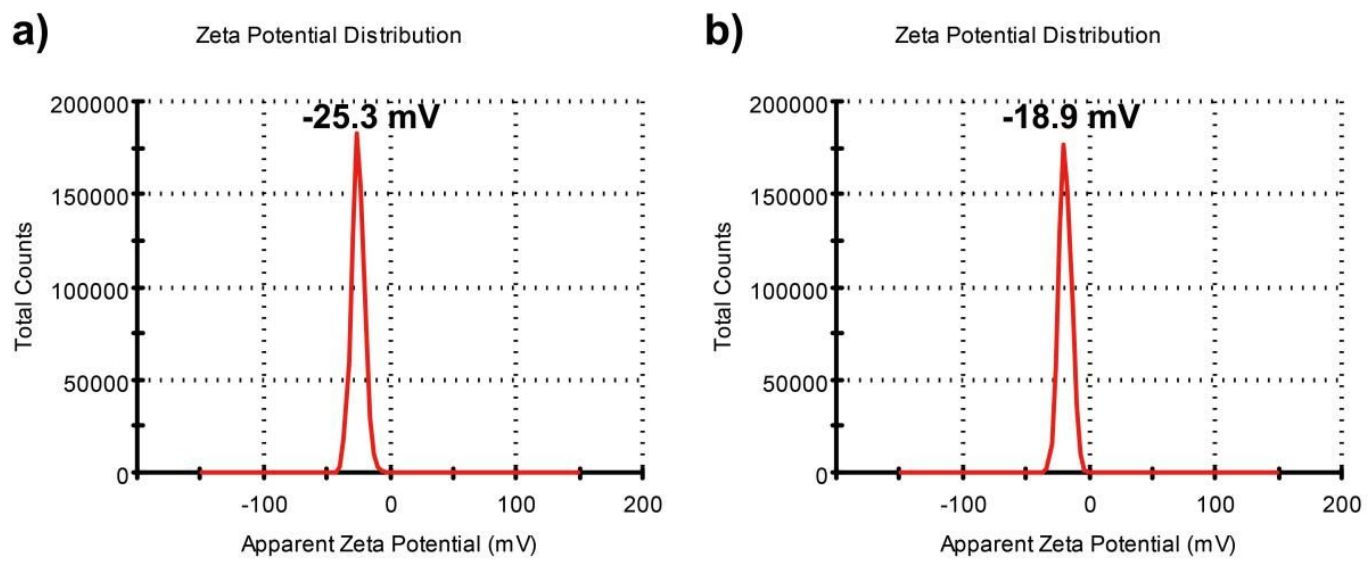

Figure S4 Zeta potentials of a) SQ1@DSPE $(10 \mu \mathrm{g} / \mathrm{mL})$ and b) SQ1 nanoprobe $(10 \mu \mathrm{g} / \mathrm{mL})$ in PBS (pH 7.4, $\left.25^{\circ} \mathrm{C}\right)$.

\section{Photostability}

The SQ1 and SQ1 nanoprobe (SQ1 NP) were exposed with a laser $\left(915 \mathrm{~nm}, 0.5 \mathrm{~W} / \mathrm{cm}^{2}, 5 \mathrm{~min}\right)$ while the cyanine dye ICG (FDA-approved NIR contrast agent) was exposed with a laser $\left(808 \mathrm{~nm}, 0.5 \mathrm{~W} / \mathrm{cm}^{2}, 5\right.$ min). During these measurements, the temperature was monitored by a thermal imaging camera. Three cycles of irradiations were also carried out (915 nm for SQ1, SQ1 nanoprobe and $808 \mathrm{~nm}$ for ICG, 0.5 $\mathrm{W} / \mathrm{cm}^{2}, 5 \mathrm{~min}$ ). The initial and max temperatures of samples in each cycle were measured. In addition, the NIR absorbance were recorded after each irradiation including for SQ1, SQ1 nanoprobe and ICG.
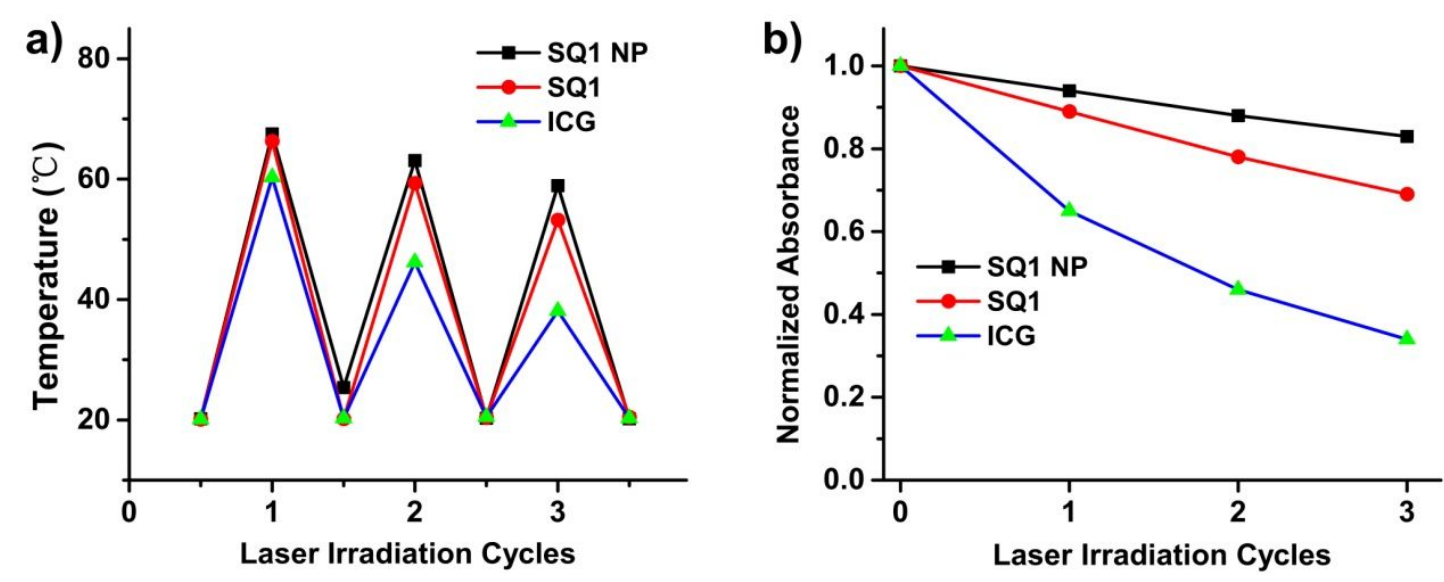

Figure S5 a) The thermal curves and b) absorbance intensity change of SQ1, SQ1 nanoprobe and ICG after repeated laser irradiation, respectively.

\section{Cell culture}

MDA-MB-231 ((human breast cancer cell line) MCF-7 (human breast adenocarcinoma cell line) and 4T1 (murine mammary carcinoma cell line) cells were purchased from Shanghai Bogoo Biotech Co., Ltd., China. Cells were cultured in RPMI-1640 (Gibco) at $37{ }^{\circ} \mathrm{C}$ under humidified conditions of $95 \%$ air and 5\% 
$\mathrm{CO}_{2}$. All media were supplemented with $10 \%$ fetal bovine serum, $100 \mathrm{U}$ penicillin and $0.1 \mathrm{mg}$ of streptomycin (Gibco) per milliliter. The culture media were changed every two days to maintain exponential growth of the cells. Cells were passaged using $0.25 \%$ Trypsin/EDTA (Sigma) when they reached $80-90 \%$ confluence and seeded for the experiments.

\section{Animals and tumor implantation}

The in vivo study and animal handling was performed in accordance with a protocol approved by the Ethics Committee of Xinhua Hospital Affiliated to Shanghai Jiao Tong University School of Medicine.

For MDA-MB-231 xenografts model: MDA-MB-231 cells were washed with PBS (pH 7.4), and harvested using $0.25 \%$ Trypsin/EDTA (Sigma). After centrifugation, the harvested cells were then suspended in PBS (pH 7.4). Four-week-old (approximately $15 \mathrm{~g}$ ) female BALB/c nude mice (Shanghai Slac Laboratory Animal Co. Ltd., China) were implanted subcutaneously on the right flank with 1 million MDA-MB-231 cells in $100 \mu \mathrm{L}$ PBS (pH 7.4), and tumors developed within four weeks.

For lung metastasis model: 4T1 cells were washed with PBS (pH 7.4), and harvested using 0.25\% Trypsin/EDTA (Sigma). After centrifugation, the harvested cells were then suspended in PBS (pH 7.4). Four-week-old (approximately $15 \mathrm{~g}$ ) female BALB/c nude mice (Shanghai Slac Laboratory Animal Co. Ltd., China) nude mice were intravenously injected with 1 million 4T1 cells cells in $100 \mu \mathrm{L}$ PBS (pH 7.4), and tumors developed within four weeks.

\section{In vivo photothermal imaging}

The mice bearing MDA-MB-231 tumors were injected with PBS $(100 \mu \mathrm{L})$ or SQ1 nanoprobe $(100 \mu \mathrm{L}, 100$ $\mu \mathrm{g}$ ) intravenously. After $12 \mathrm{~h}$, the tumors of mice in these two groups were exposured to a $915 \mathrm{~nm}$ NIR laser at $0.5 \mathrm{~W} / \mathrm{cm}^{2}$ for $5 \mathrm{~min}$. At the same time, the photohermal imaging of tumor-bearing mice were acquired with an IR camera every $30 \mathrm{~s}$ for $5 \mathrm{~min}$.

In vivo photothermal therapy. When the tumor sizes reached about $100 \mathrm{~mm}^{3}$ after inoculation of MDA-MB-231 cells, the mice were parted into four groups ( $n=5$ per group) for different treatments: PBS alone; PBS plus NIR laser at $0.5 \mathrm{~W} / \mathrm{cm}^{2}$ for $5 \mathrm{~min}$ (PBS + L); SQ1 nanoprobe at $5 \mathrm{mg} / \mathrm{kg}$ alone (SQ1 NP); SQ1 nanoprobe at $5 \mathrm{mg} / \mathrm{kg}$ with NIR laser at $0.5 \mathrm{~W} / \mathrm{cm}^{2}$ for $5 \mathrm{~min}$ (SQ1 NP $+\mathrm{L}$ ). After intravenous injection and NIR irradiation, the tumor sizes (length and width) and body weights were acquired with an electronic vernier caliper. Tumor sizes were calculated by this formula: tumor volume $=\mathrm{A} \times \mathrm{B}^{2} \times 0.5$. In this formula, A and B represents the length and width of tumors, respectively.

\section{Histological examination of organs and tumors}

Freshly dissected heart, liver, kidneys, lungs, stomach, spleen, stomach and tumor from mice were fixed in 
$4 \%$ paraformaldehyde solution for $24 \mathrm{~h}$. The organs were embedded in paraffin and cut into $4-\mu \mathrm{m}$ slices. After that, the sections were deparaffinized and stained with Hematoxylin and Eosin solution. Finally, the sections were dehydrated and mounted with Permount in a fume hood. The sections were scanned by a microscope (Nikon, Japan).

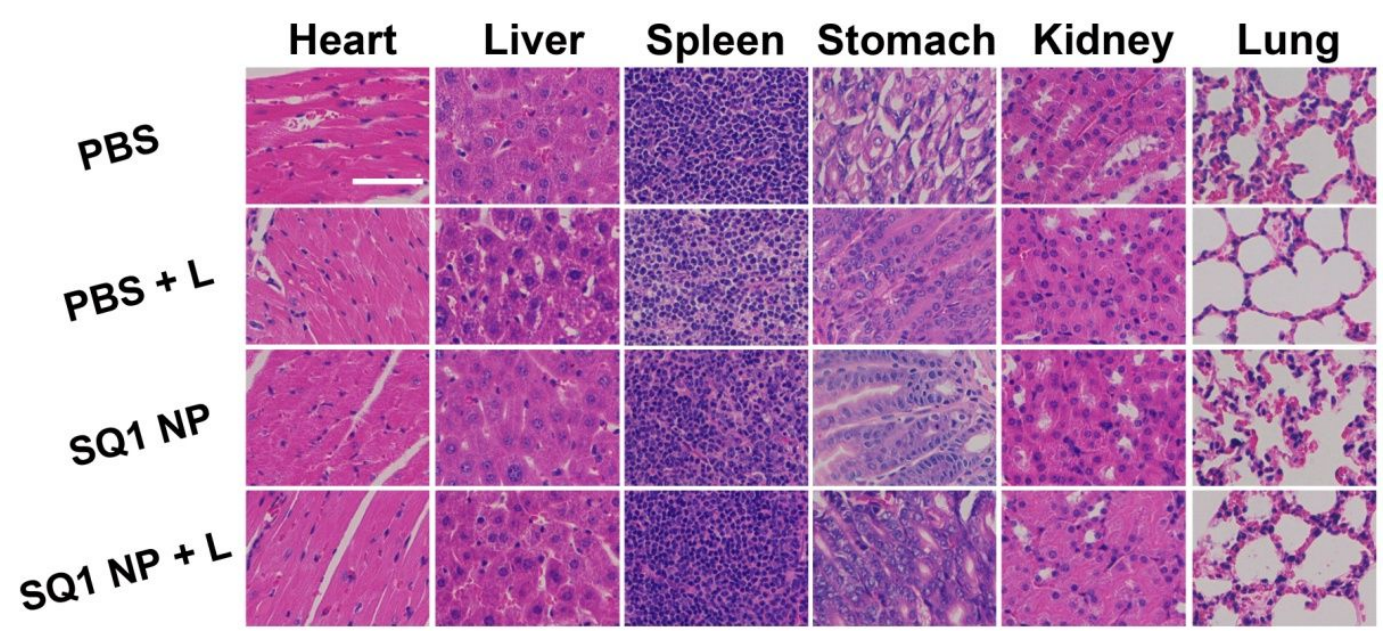

Figure S6 At the termination of the experiments, H\&E staining of the paraffin sections of organs including heart, liver, spleen, lungs, kidneys and stomach from mice treated with PBS, PBS with NIR laser (L), SQ1 nanoprobe only, and SQ1 nanoprobe with NIR laser. Scale bar is $50 \mu \mathrm{m}$.

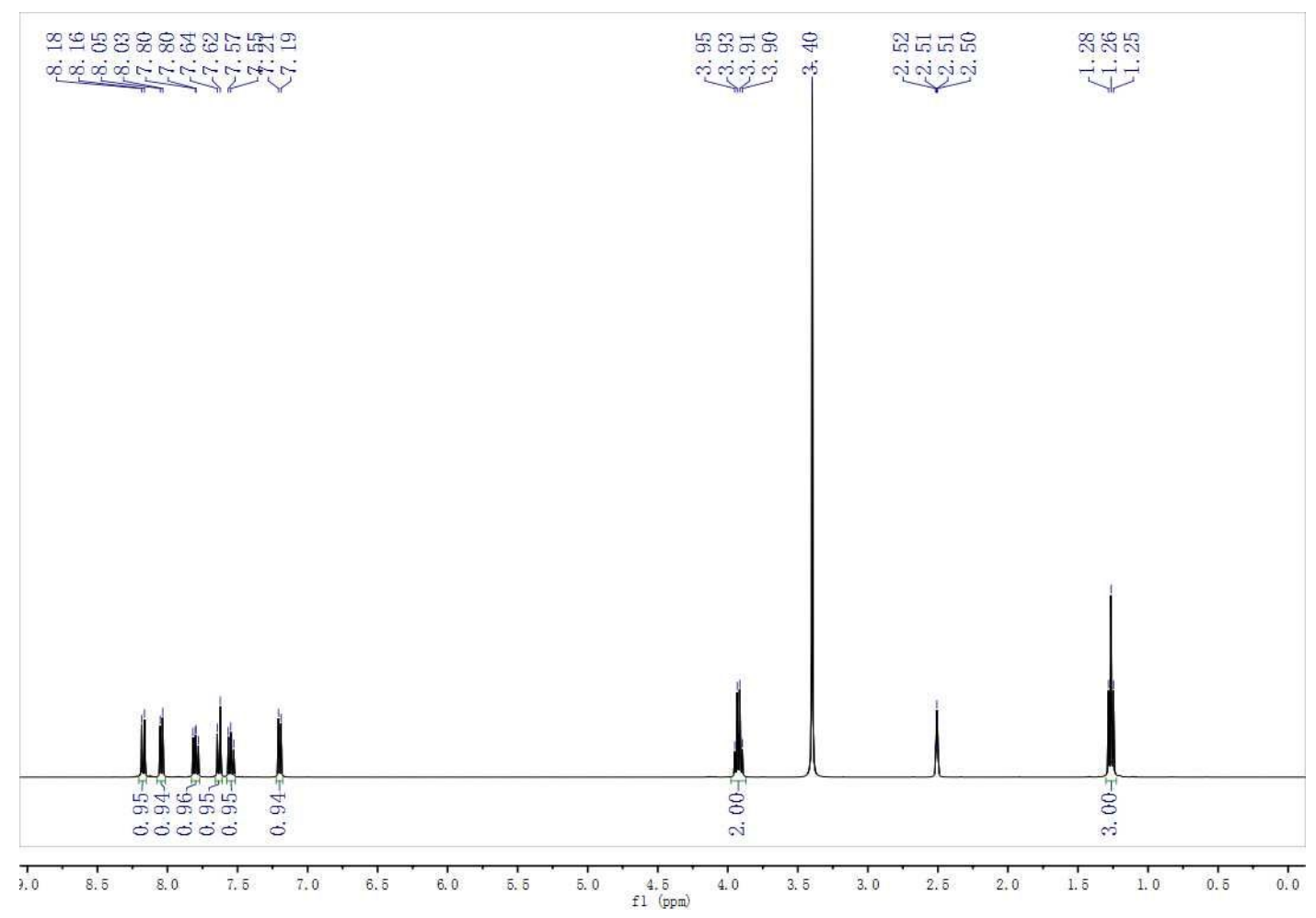

Figure $\mathbf{S} 7{ }^{1} \mathrm{H}$ NMR spectrum of compound 2 in DMSO- $d_{6}$. 


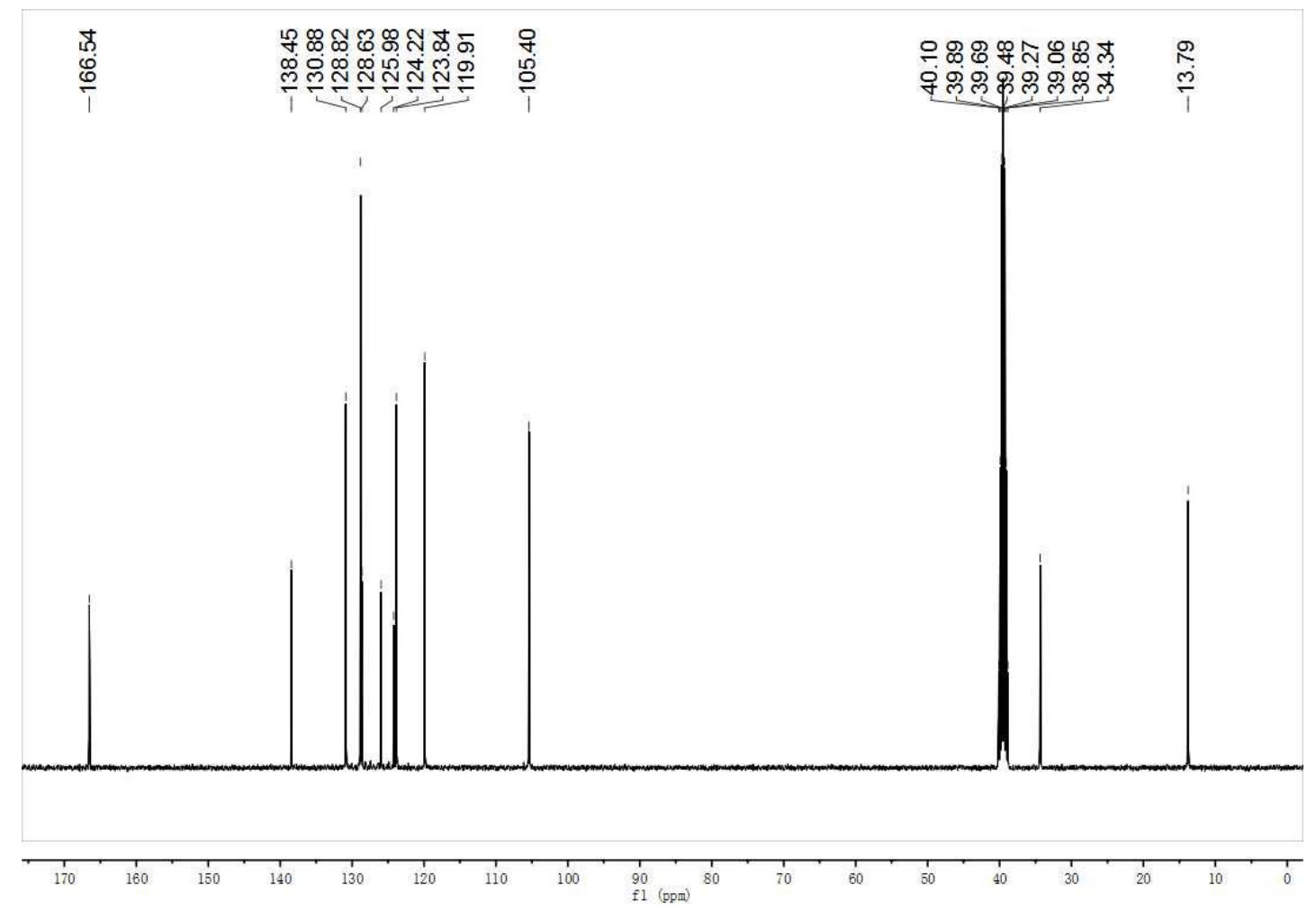

Figure S8 ${ }^{13} \mathrm{C}$ NMR spectrum of compound 2 in DMSO- $d_{6}$.

\section{Elemental Composition Report}

Single Mass Analysis

Tolerance $=5.0$ PPM I DBE: $\min =-1.5, \max =50.0$

Element prediction: Off

Number of isotope peaks used for i-FIT $=2$

Monoisotopic Mass, Even Electron Ions

5 formula(e) evaluated with 1 results within limits (up to 50 best isotopic matches for each mass)

$\begin{array}{llll}\text { C: } 0-13 & \text { H: } 0-76 & \text { N: }: 0-1 & \text { O: } 0-1\end{array}$

WH-ZHU

ZW-GKZ-1 66 (0.748) Cm (65:67)

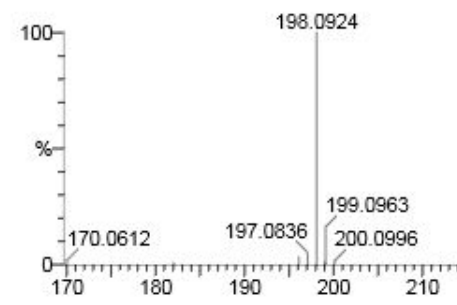

220.0747

Minimum:

Maximum:

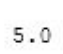

5.0

-1.5
50.0

Mass

Calc. Mass

$\mathrm{mDa}$

PPM

DBE

i-FIT

i-FIT (Norm) Formula

198.0924

198.0919

0.5

2.5

$8.5 \quad 18.1$

0.0

C13 H12 N

Figure S9 ESI-MS spectrum of compound 2. 


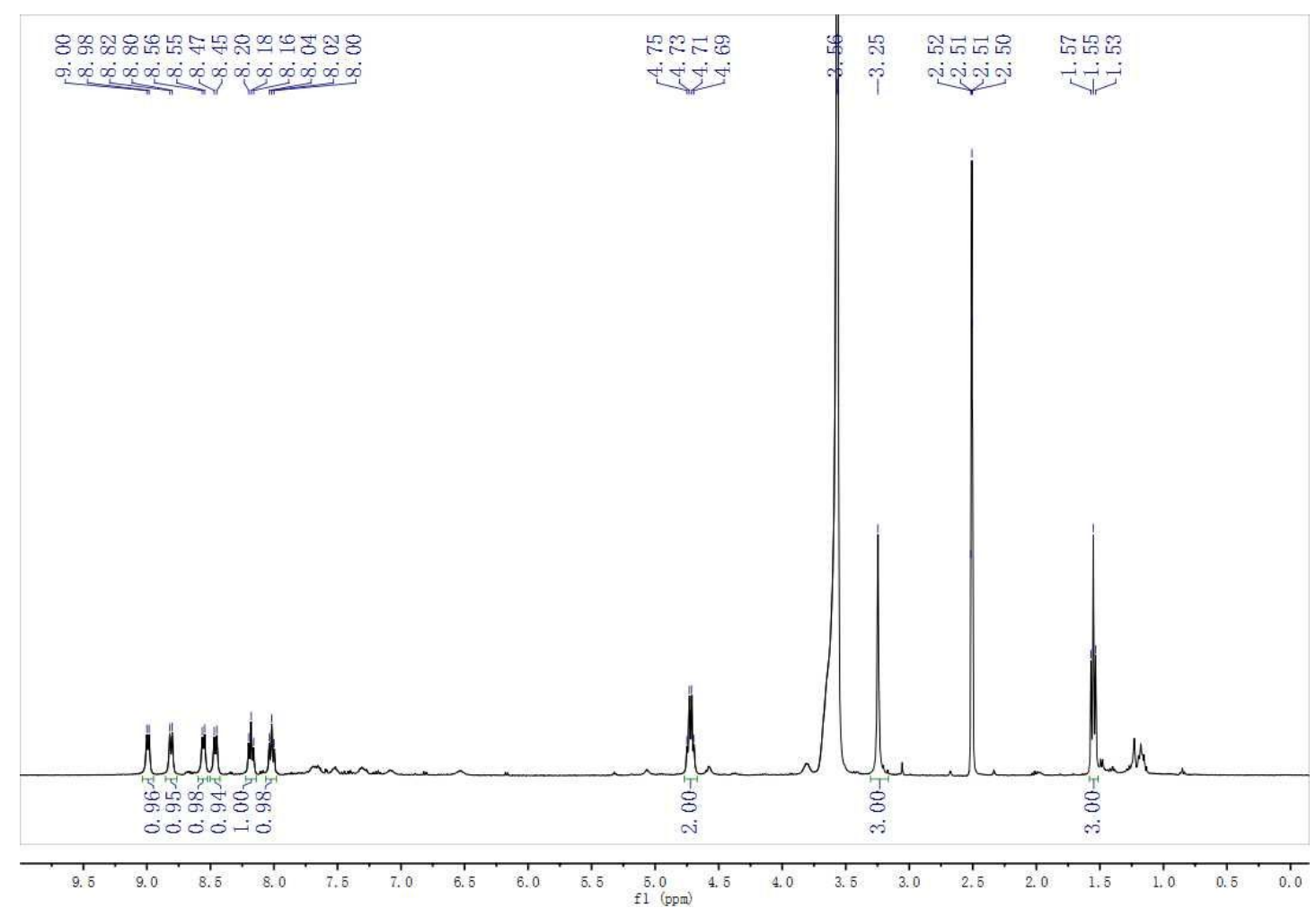

Figure S10 ${ }^{1} \mathrm{H}$ NMR spectrum of compound 3 in DMSO- $d_{6}$.

Elemental Composition Report

Single Mass Analysis

Tolerance $=5.0$ PPM I DBE: $\min =-1.5, \max =50.0$
Element prediction: Off

Number of isotope peaks used for i-FIT $=2$

Monoisotopic Mass, Even Electron lons

3 formula(e) evaluated with 1 results within limits (up to 50 best isotopic matches for each mass)

Elements Used:

$\begin{array}{lll}\text { C: } 0-14 & \text { H: } 0-76 \quad \mathrm{~N}: 0-1\end{array}$

WH-ZHU

ZW-GKZ-2 66 (0.749) Cm (66:68)

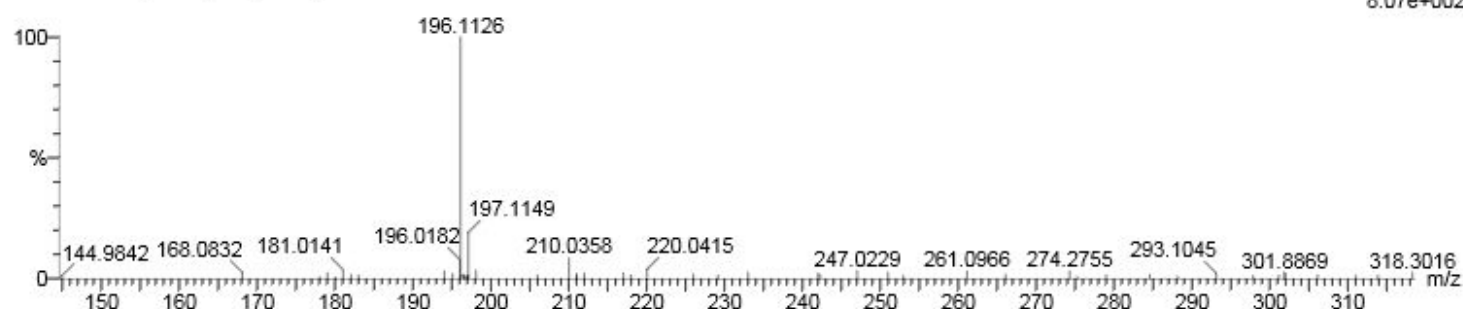

Minimum:

Maximum:

$\begin{array}{lll}5.0 & 5.0 \quad & -1.5 \\ & 50.0\end{array}$

Mass

Calc. Mass

$\mathrm{mDa} \quad \mathrm{PPM}$

$\mathrm{DBE}$

i-FIT

i-FIT (Norm) Formula

196.1126

196.1126

0.0

0.0

8.5

35.4

0.0

C14 H14 N

Figure S11 ESI-MS spectrum of compound 2. 


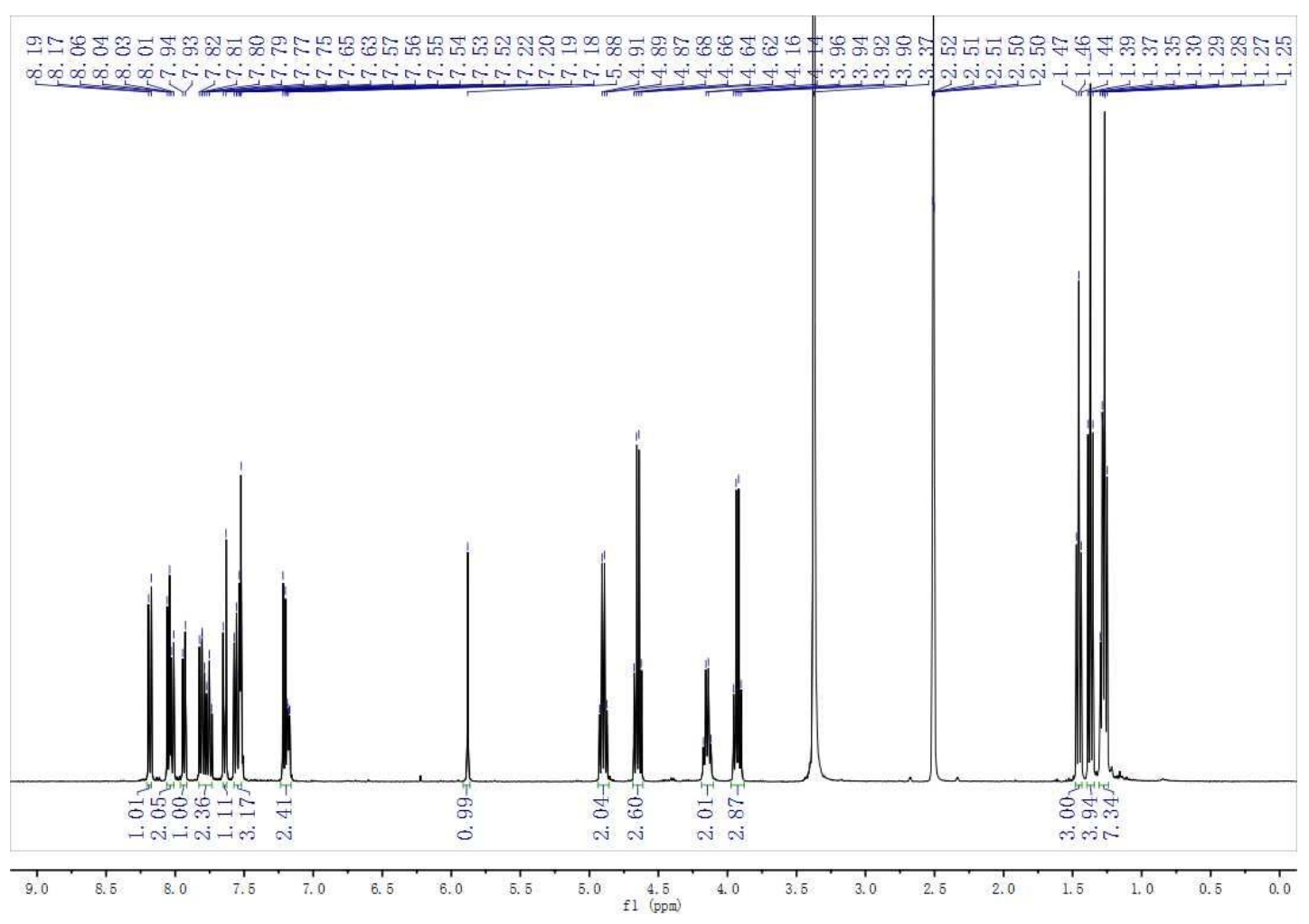

Figure S12 ${ }^{1} \mathrm{H}$ NMR spectrum of compound 3 in DMSO- $d_{6}$.
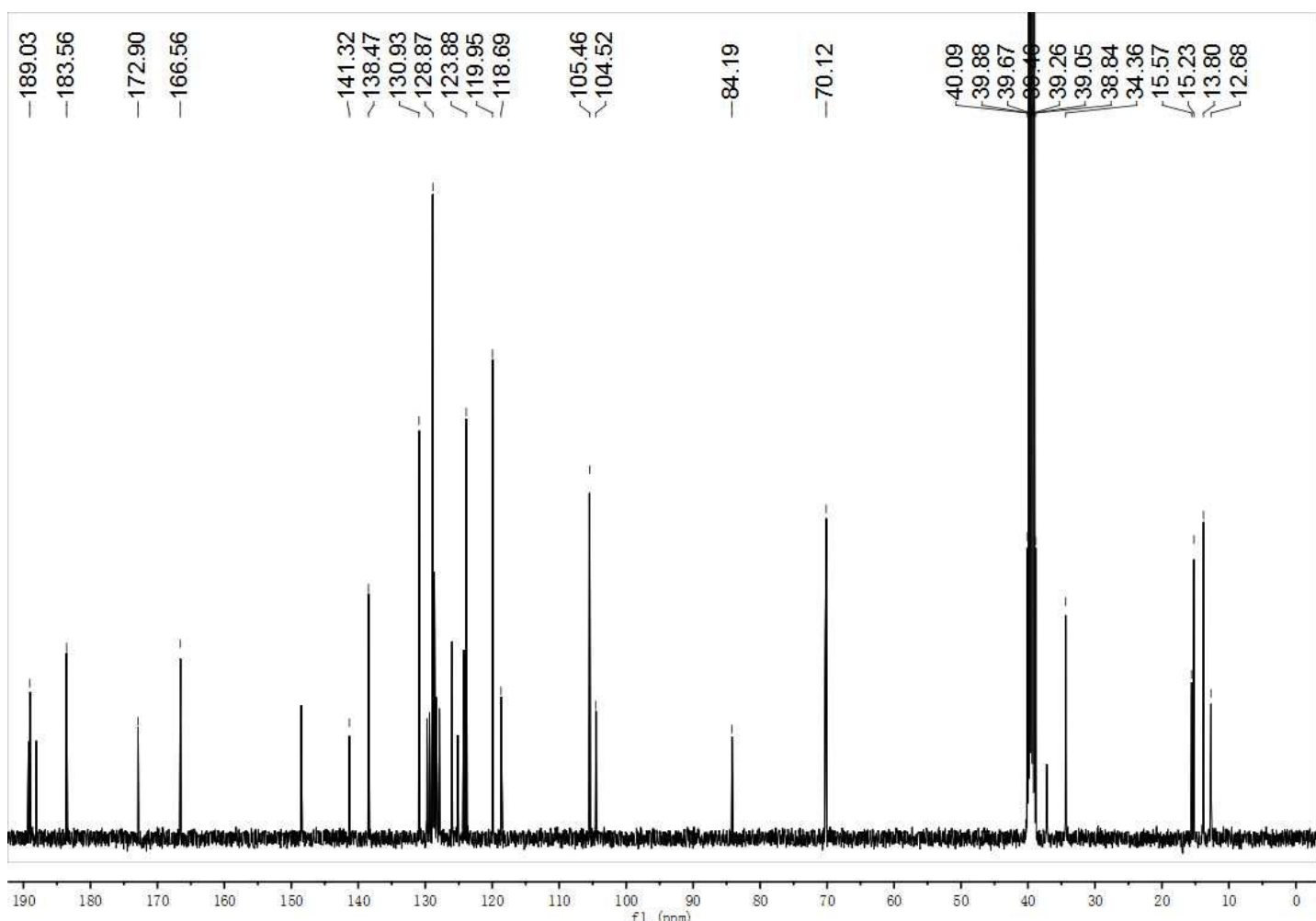

Figure S13 ${ }^{13} \mathrm{C}$ NMR spectrum of compound 4 in DMSO- $d_{6}$. 


\section{Single Mass Analysis}

Tolerance $=5.0$ PPM / DBE: $\min =-1.5, \max =50.0$
Element prediction: Off

Number of isotope peaks used for i-FIT $=2$

Monoisotopic Mass, Even Electron Ions

20 formula(e) evaluated with 1 results within limits (up to 50 best isotopic matches for each mass)

Elements Used:

$\begin{array}{lllll}\text { C: } 0-20 & \text { H: } 0-76 & \text { N: } 0-1 & \text { O: } 0-3 & \text { Na: } 0-1\end{array}$

WH-ZHU

ZW-GKZ-3 37 (0.406) Cm (37:38)

$100-$
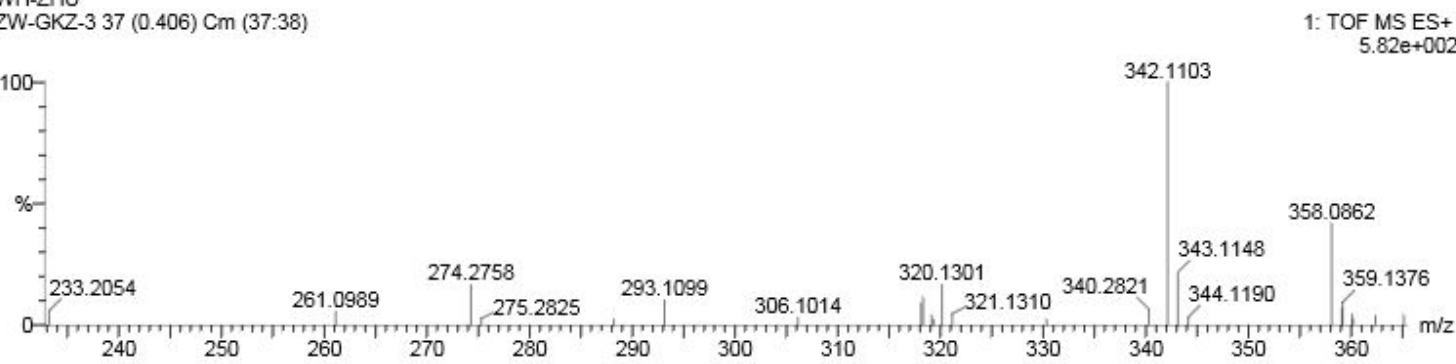

Minimum:

Maximum:

$\begin{array}{lll}5.0 & 5.0 & -1.5 \\ & 50.0\end{array}$

Mass

Calc. Mass

$\mathrm{mDa} \quad \mathrm{PPM}$

$\mathrm{DBE}$

i-FIT

i-FIT (Norm) Formula

342.1103

342.1106

$-0.3-0.9$

12.5

6.9

0.0

$\mathrm{C} 2 \mathrm{O}$ H17 $\mathrm{N} \quad \mathrm{O} 3 \mathrm{Na}$

Figure S14 ESI-MS spectrum of compound 4.

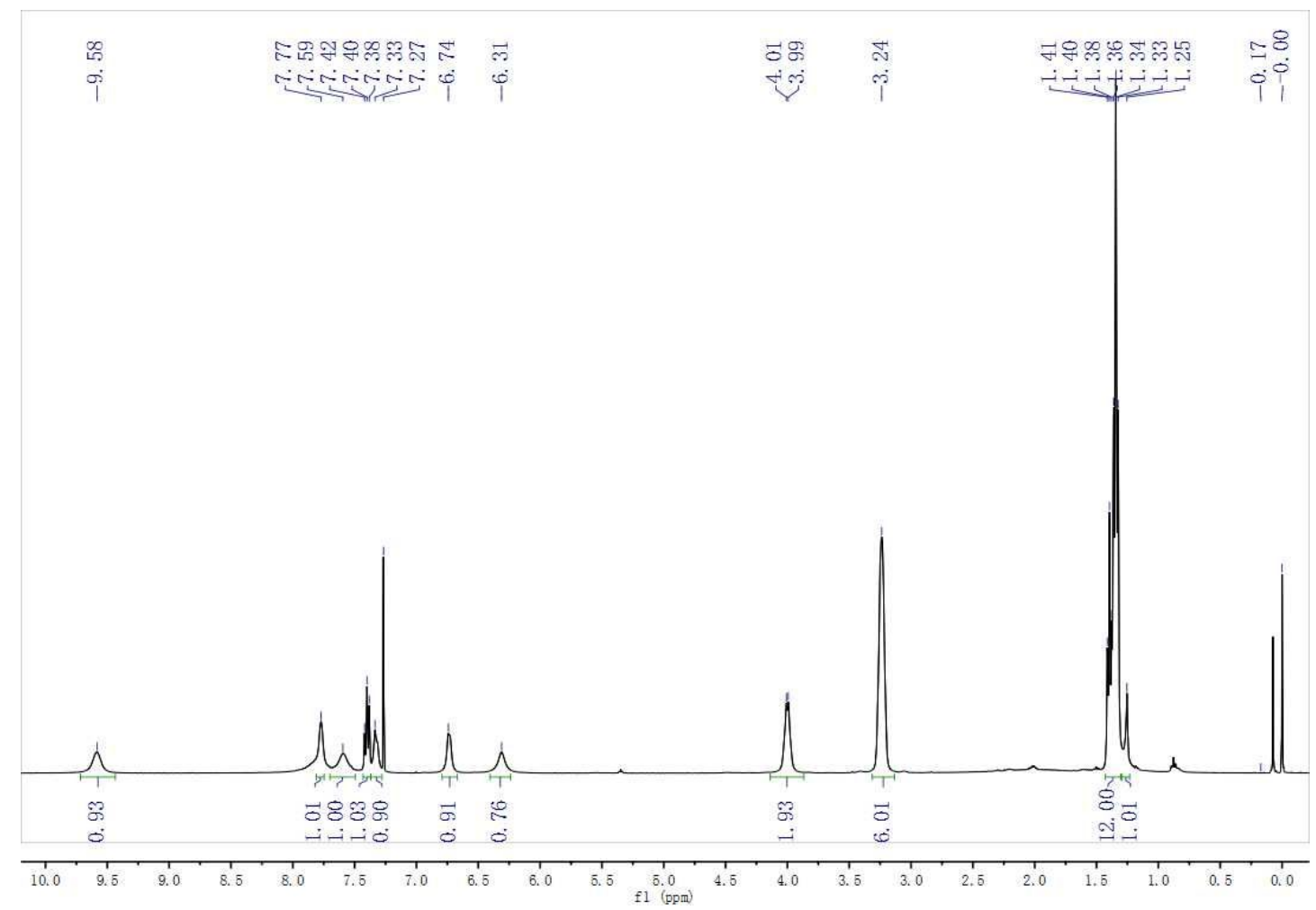

Figure $\mathbf{S 1 5}{ }^{1} \mathrm{H}$ NMR spectrum of compound 5 in $\mathrm{CDCl}_{3}$. 


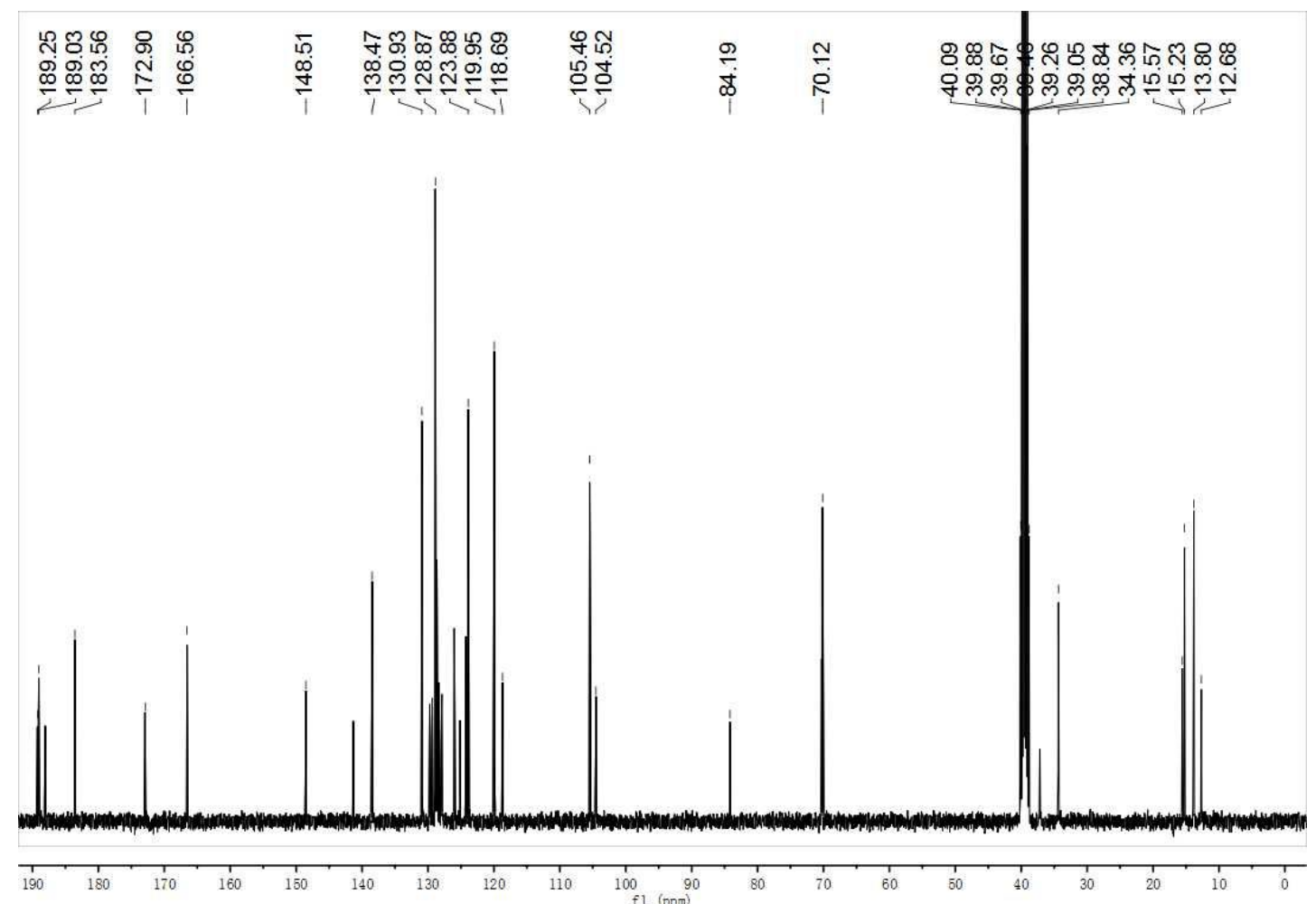

Figure S16 ${ }^{13} \mathrm{C}$ NMR spectrum of compound 5 in DMSO- $d_{6}$.

Elemental Composition Report

Page 1

Single Mass Analysis

Tolerance $=5.0$ PPM / DBE: $\min =-1.5, \max =50.0$

Element prediction: Off

Number of isotope peaks used for i-FIT $=2$

Monoisotopic Mass, Even Electron Ions

21 formula(e) evaluated with 1 results within limits (up to 50 best isotopic matches for each mass)

$\begin{array}{llll}\text { Clements } 0-21 & \text { H: } 0-76 & \mathrm{~N}: 0-3 & \mathrm{O}: 0\end{array}$

ZW-GKZ-4 $82(0.933) \mathrm{Cm}(78: 82)$

1: TOF MS ES-
$6.06 \mathrm{e}+004$

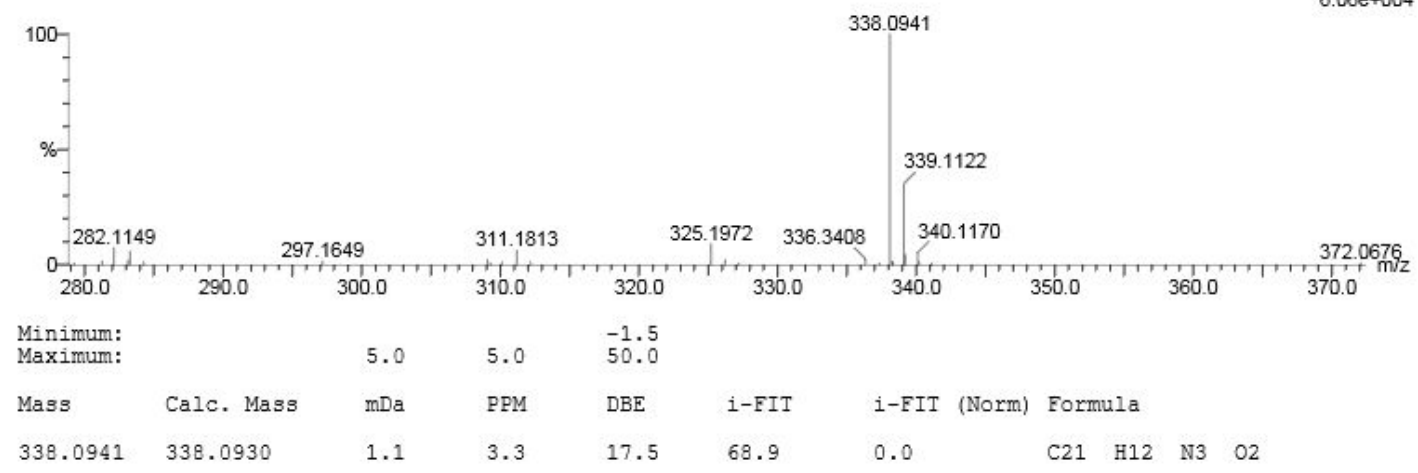

Figure S17 ESI-MS spectrum of compound 5. 
Single Mass Analysis

Tolerance $=5.0$ PPM / DBE: $\min =-1.5, \max =50.0$

Element prediction: Off

Number of isotope peaks used for $\mathrm{i}-\mathrm{FIT}=2$

Monoisotopic Mass, Even Electron Ions

24 formula(e) evaluated with 1 results within limits (up to 50 closest results for each mass)

Elements Used

$\begin{array}{llll}\text { C: } 0-35 & H: 0-61 & N\end{array}: 0-4 \quad 0: 0-2$

WH-ZHU

ZW-GKZ-0911-2 56 (0.626) Cm (55:61)

1: TOF MS ES+

100

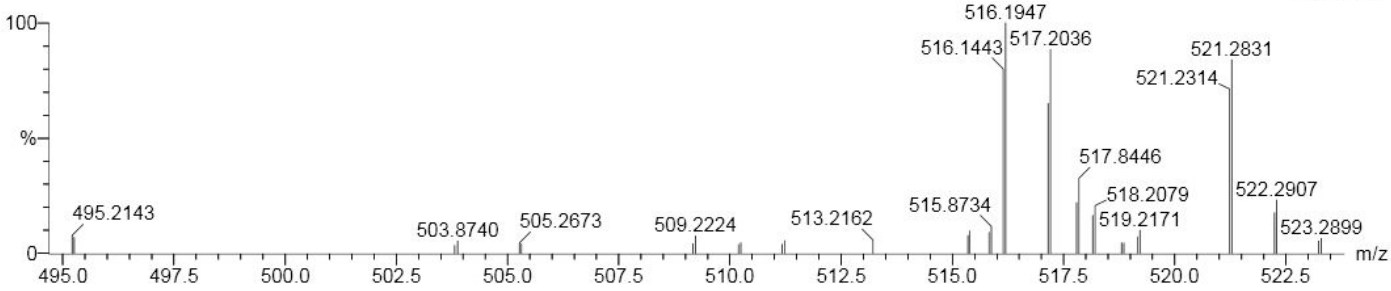

Minimum:

Maximum:

$5.0 \quad 5.0 \quad 50.0$

Mass Calc. Mass mDa PPM DBE i-FIT i-FIT (Norm) Formula

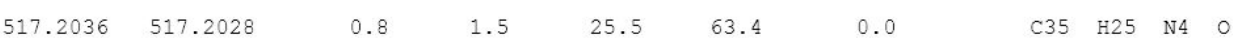

Figure S18 ESI-MS spectrum of SQ1.

Elemental Composition Report

Page 1

Single Mass Analysis

Tolerance $=5.0$ PPM / DBE: $\min =-1.5, \max =50.0$

Element prediction: Off

Number of isotope peaks used for i-FIT $=2$

Monoisotopic Mass, Even Electron lons

12 formula(e) evaluated with 1 results within limits (up to 50 closest results for each mass)

Elements Used:

$\begin{array}{llll}\text { C: } 0-32 & \mathrm{H}: 0-61 & \mathrm{~N}: 0-2 & \mathrm{O}: 0-2\end{array}$

$\mathrm{WH}-\mathrm{ZHU}$

ZW-GKZ-0911-1 20 (0.212) Cm (10:29)

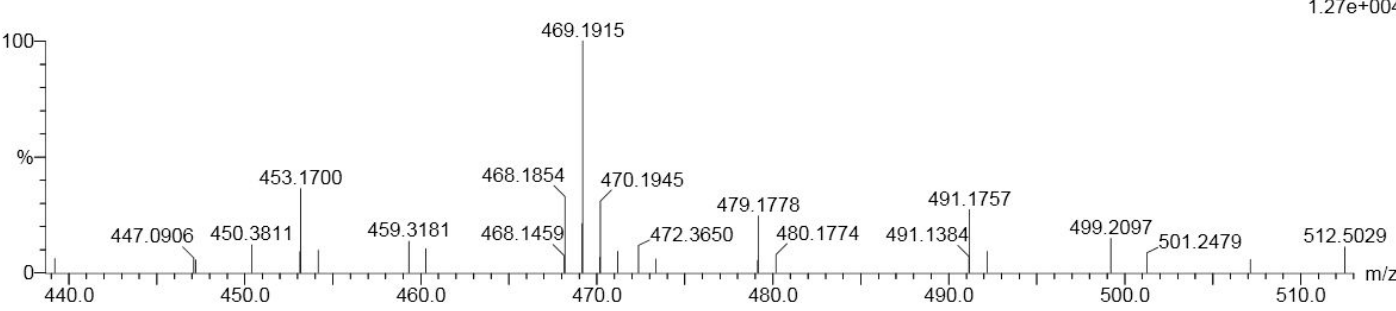

Minimum:

Maximum:

$\begin{array}{lll} & & -1.5 \\ & 5.0 & 50.0\end{array}$

Mass Calc. Mass mDa PPM DBE i-FIT i-FIT (Norm) Formula

$\begin{array}{lllllllllllll}469.1915 & 469.1916 & -0.1 & -0.2 & 21.5 & 26.5 & 0.0 & \text { C32 } & \text { H25 } & \text { N2 } & \text { O2 }\end{array}$

Figure S19 ESI-MS spectrum of SQ2. 